\title{
Article \\ Flow Cytometry-Based Determination of Ploidy from Dried Leaf Specimens in Genomically Complex Collections of the Tropical Forage Grass Urochloa s. 1.
}

\author{
Paulina Tomaszewska ${ }^{1}, * \mathbb{D}$, Till K. Pellny ${ }^{2}$, Luis M. Hernández ${ }^{3}$, Rowan A. C. Mitchell ${ }^{2}$, Valheria Castiblanco ${ }^{3}$, \\ José J. de Vega ${ }^{4}$, Trude Schwarzacher ${ }^{1}$ and Pat (J.S.) Heslop-Harrison ${ }^{1}[$ \\ 1 Department of Genetics and Genome Biology, University of Leicester, University Road, \\ Leicester LE1 7RH, UK; ts32@leicester.ac.uk (T.S.); phh4@leicester.ac.uk (P.H.-H.) \\ 2 Rothamsted Research, Harpenden, Hertfordshire AL5 2JQ, UK; till.pellny@gmail.com (T.K.P.); \\ rowan.mitchell@rothamsted.ac.uk (R.A.C.M.) \\ 3 International Center for Tropical Agriculture (CIAT), Cali 6713, Colombia; 1.hernandez@cgiar.org (L.M.H.); \\ V.Castiblanco@cgiar.org (V.C.) \\ $4 \quad$ Earlham Institute, Norwich Research Park, Norwich NR4 7UZ, UK; Jose.De-Vega@earlham.ac.uk \\ * Correspondence: pt186@leicester.ac.uk
}

Citation: Tomaszewska, P.; Pellny, T.K.; Hernández, L.M.; Mitchell, R.A.C.; Castiblanco, V.; de Vega, J.J.; Schwarzacher, T.; Heslop-Harrison, P. Flow Cytometry-Based Determination of Ploidy from Dried Leaf Specimens in Genomically Complex Collections of the Tropical Forage Grass Urochloa s. 1. Genes 2021, 12, 957. https://doi.org/10.3390/ genes12070957

Academic Editors: Elwira Sliwinska, Monika Rewers and Iwona Jedrzejczyk

Received: 26 March 2021

Accepted: 16 June 2021

Published: 23 June 2021

Publisher's Note: MDPI stays neutral with regard to jurisdictional claims in published maps and institutional affiliations.

Copyright: (c) 2021 by the authors. Licensee MDPI, Basel, Switzerland. This article is an open access article distributed under the terms and conditions of the Creative Commons Attribution (CC BY) license (https:// creativecommons.org/licenses/by/ $4.0 /)$

\begin{abstract}
Urochloa (including Brachiaria, Megathyrus and some Panicum) tropical grasses are native to Africa and are now, after selection and breeding, planted worldwide, particularly in South America, as important forages with huge potential for further sustainable improvement and conservation of grasslands. We aimed to develop an optimized approach to determine ploidy of germplasm collection of this tropical forage grass group using dried leaf material, including approaches to collect, dry and preserve plant samples for flow cytometry analysis. Our methods enable robust identification of ploidy levels (coefficient of variation of G0/G1 peaks, CV, typically <5\%). Ploidy of some 348 forage grass accessions (ploidy range from $2 x$ to $9 x$ ), from international genetic resource collections, showing variation in basic chromosome numbers and reproduction modes (apomixis and sexual), were determined using our defined standard protocol. Two major Urochloa agamic complexes are used in the current breeding programs at CIAT and EMBRAPA: the 'brizantha' and 'humidicola' agamic complexes are variable, with multiple ploidy levels. Some $U$. brizantha accessions have odd level of ploidy $(5 x)$, and the relative differences in fluorescence values of the peak positions between adjacent cytotypes is reduced, thus more precise examination of this species is required. Ploidy measurement of $U$. humidicola revealed aneuploidy.
\end{abstract}

Keywords: ploidy; flow cytometry; apomixis; dried specimens; Brachiaria; Panicum; tropical forage grasses

\section{Introduction}

Understanding the genome compositions of species within complexes including diploid and polyploid species is critical to evaluate their biodiversity, for conservation and to evaluate the potential for use in breeding; measurement of genome size, across potentially large germplasm collections, underpins such work. Grasslands and rangelands with grasses as the dominant species, being the largest ecosystems in the world, are the basic feed resources for livestock, and contribute to the livelihoods of over 800 million people including smallholders (Food and Agriculture Organization of the United Nations; http: / / www.fao.org/, accessed on 25 March 2021). Only 100-150 of the 10,000 forage species have been extensively cultivated, but many more have great potential for sustainable agriculture, and improvement and conservation of grasslands, including the genus Urochloa (previously classified in Brachiaria, and some Eriochloa, Panicum and Megathyrsus) [1] comprising species native to tropical and subtropical regions of Africa. The great forage potential of these grasses have been recognized in the 1950s [2], leading to the acquisition of 
700 accessions of Urochloa and related genera during the joint collection mission of CGIAR (Consultative Group on International Agricultural Research) lead centers: CIAT (Centro Internacional de Agricultura Tropical) and ILRI (International Livestock Research Institute) in Africa in the 1980s. Five species of Urochloa: U. ruziziensis, U. decumbens and U. brizantha (belonging to the 'brizantha' agamic complex), U. humidicola (belonging to the 'humidicola' agamic complex), and U. maxima were then introduced in South America, and have been used as fodder plants mainly in Colombia and Brazil [3].

In exploiting biodiversity in breeding, improvements in yield and nutritional quality of forages can be achieved by identifying genes increasing the digestibility of plant cell walls and the protein and lipid content in vegetative tissues, and increasing biomass production [4]. By introduction to plant breeding programmes, genetic improvement of forage lines, recurrent genetic selection of plants showing useful traits, and subsequent hybridizations and back-crossings [5,6], create more diverse agroecosystems resilient to climate and environmental changes [7]. The DNA amount measurement for ploidy and genome size estimation, and the characterization of genome composition are required for effective use of diploids and polyploids in breeding programs, as well as for research purposes [8,9].

Preparation of metaphases from dividing plant tissues, followed by microscopy and chromosome counting, is widely used to determine the ploidy of individual plants and show polyploid series within larger groups. However, the method is time-consuming and highly skilled, both in terms of growing plants and collecting root-tips or meiotic material, and in making the preparations. The most rapid and convenient technique for ploidy measurement is flow cytometry using suspensions of fluorescently labeled nuclei [10-14], that is now widely adopted for fresh leaf specimens.

Phenolics, hydroxamic acids, and short-chain fatty acids are present in plants, and some of these phytochemicals have been identified as inhibitors of fluorescent DNA staining, hence leading to inaccurate flow cytometry-based measurement of DNA content [15-19]. The ability of tropical and subtropical plants to synthesize secondary metabolites and possess allelopathic potential is exceptional [20]. Seasonal and regional differences in accumulation of secondary products may cause differences in staining for flow cytometry. Secondary metabolites and their phytotoxicity on forage legumes have been recognized in Urochloa tropical forage grasses [21-24], which has been suggested to make it difficult to analyze these plants by flow cytometry [25].

For Urochloa, ploidy estimation across the whole germplasm collection (excluding one species, $U$. ruziziensis, known only as a diploid) is required due to the different pathways of reproduction showing sexual and apomictic accessions within same species [26], natural triploid interspecific hybrids [27], different genome compositions both within and between species [9], confirmed aneuploidy $[9,28,29]$, and different basic chromosome numbers $(x=6,8$ and 9$)$ [30-35].

Ideally, a common reference standard for flow cytometry and ploidy measurement should be a diploid plant from the taxon of the tested samples, grown and collected under similar conditions, and where chromosomes can be prepared and counted. For a pool with diverse ploidies, several standards are helpful, although the lack of seeds or living plants may make it impossible to prepare metaphase plates from root tips, and challenges (e.g., due to apomictic mode of reproduction of studied species, difficulties with germination of tropical plant seeds, or having only herbarium samples), may mean a less related standard with known ploidy level, genome size and basic chromosome number similar to the unknown samples must be used [14]. 
Fresh leaves have usually been considered the best material for flow cytometry analysis. However, there is often a requirement for use of field-material, collected under suboptimal demanding conditions compared to plants for greenhouse or experimental field and requiring storage and transport to the flow cytometry facility. Additionally, work often needs to use herbarium or stored material, which may not be possible to collect again, or is the reference for published studies, or is determined as a new species/taxonomic revision, requiring determination of ploidy and estimation of genome size [36]. The applicability of flow cytometry for dehydrated leaves is limited by several factors, including insufficient amounts of tissue, sampling of mature plants, incorrect drying, storage and preservation of samples, and the low efficiency of nuclei isolation due to their degradation.

For flow cytometry analysis of nuclear genome sizes from fresh and dried material, coefficient of variation of the G0/G1 peak (CV), that quantifies a precision of individual flow cytometry measurements, is an important criterion showing estimation of nuclei integrity and variation in DNA staining [37-42]. Low coefficient of variation, even for dried leaf specimens [36], or seeds [19], petals and pollen [43], can be achieved by using appropriate isolation buffers and their supplementation, stains and staining protocols, the practical technique used for chopping leaves in the buffer, and even choice of razor blades.

Here, we aimed to develop an optimized and robust approach to determine ploidy of tropical forage grasses using dried leaf material. The established method can be widely adopted for dried leaf specimens, especially when screening genomically variable germplasm resource collections, defining a standard protocol recommendation. More specifically, we intended to optimize the flow cytometry assay for Urochloa grass group that shows variation in basic chromosome numbers and reproduction modes.

\section{Materials and Methods}

\subsection{Plant Material}

Accessions of Urochloa and related species used in the study are listed in Supplementary Data Table S1. Plants used as external standards, and their seed providers are given in Table 1. Leaf samples intended for flow cytometry analysis were collected from germplasm accessions grown and maintained in the field genebank at CIAT Palmira campus (Figure 1).

Table 1. External standards used for flow cytometry analysis of Urochloa germplasm collection. Chromosome numbers were counted microscopically.

\begin{tabular}{|c|c|c|c|}
\hline External Standard & $\begin{array}{l}\text { Number of } \\
\text { Chromosomes }\end{array}$ & $\begin{array}{l}\text { Mean Fluorescence Values } \\
\text { of the Peak Positions }\end{array}$ & Sample Species \\
\hline Panicum miliaceum VIR, Mil69 & $2 n=4 x=36$ & 112 & - \\
\hline $\begin{array}{l}\text { Urochloa brizantha, USDA, } \\
\text { PI } 292187\end{array}$ & $2 n=4 x=36$ & 225 & $\begin{array}{l}\text { U. brizantha, U. dura, U. platynota, U. ruziziensis } \\
\times \text { U. decumbens } \times \text { U. brizantha hybrid }\end{array}$ \\
\hline Urochloa decumbens, CIAT, 664 & $2 n=4 x=36$ & 205 & $\begin{array}{c}\text { U. arrecta, U. decumbens, U. jubata, } \\
\text { U. nigropedata, U. plantaginea, U. ruziziensis }\end{array}$ \\
\hline Urochloa decumbens, CIAT, 6370 & $2 n=4 x=36$ & 194 & $\begin{array}{c}\text { U. arrecta, U. decumbens, U. jubata, } \\
\text { U. nigropedata, U. plantaginea, U. ruziziensis }\end{array}$ \\
\hline Urochloa humidicola, CIAT, 26151 & $2 n=6 x=36$ & 197 & U. humidicola, U. dictyoneura \\
\hline Urochloa maxima, CIAT, 6171 & $2 n=4 x=32$ & 131 & U. maxima, U. nigropedata \\
\hline Urochloa maxima, CIAT, 16004 & $2 n=4 x=32$ & 120 & U. maxima, U. nigropedata \\
\hline Urochloa maxima, USDA, PI 284156 & $2 n=4 x=32$ & 149 & U. maxima, U. nigropedata \\
\hline Urochloa ruziziensis, CIAT, 6419 & $2 n=2 x=18$ & 83 & $\begin{array}{c}\text { U. arrecta, U. decumbens, U. jubata, } \\
\text { U. nigropedata, U. plantaginea, U. ruziziensis }\end{array}$ \\
\hline Urochloa sp., USDA, PI 657653 & $2 n=4 x=32$ & 111 & U. maxima \\
\hline
\end{tabular}

United States Department of Agriculture (USDA, USA); Vavilov Research Institute (VIR, St Petersburg, Russia); Centro Internacional de Agricultura Tropical (CIAT, Colombia). 


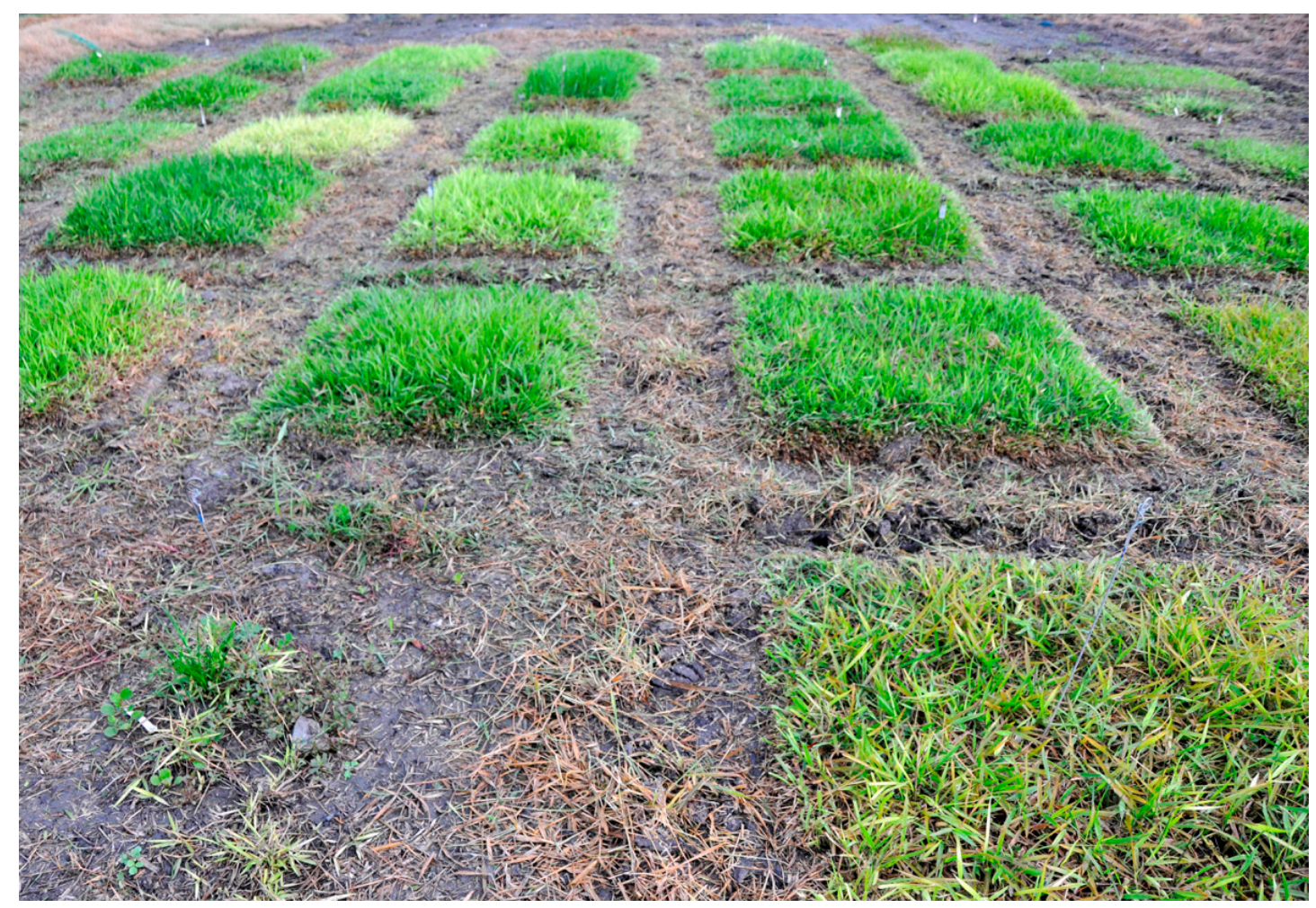

Figure 1. Field plots of Urochloa tropical forage grasses in CIAT, Colombia.

\subsection{Collection and Preservation of Plant Material for Flow Cytometry}

1. Leaf fragments of approximately $1 \mathrm{~g}$ fresh weight were harvested in the field, folded into permeable manila seed storage envelopes $(80 \mathrm{gsm})$ and kept in a sealed plastic bag on wet ice. Young leaves from typical vigorous specimens, representative of the population in each plot, were selected. Insect damaged and discolored plants were avoided.

2. The envelopes were then stored in a sealed desiccator at ambient pressure, or an airtight plastic box (as used for sandwiches or larger sizes), at room temperature with a thick layer of self-indicating silica gel (a granular material with c. $3-5 \mathrm{~mm}$ irregular beads; Type III Sigma-Aldrich, S7625; or self-indicating mixed with non-indicating silica gel, cheaply available from online marketplaces). The silica gel was changed daily until it did not change color, which was after approximately 4-5 days. In total, $250 \mathrm{~g}$ of silica gel was used for 30 leaf samples.

3. Multiple samples in the paper envelopes were then transferred to sealed plastic bags with a small amount of silica gel.

4. The plastic bags with envelopes of dried leaves and silica gel were shipped under ambient conditions to the University of Leicester, UK (with appropriate export and import documentation, here under "Section IV: Cut flowers, foliage and vegetables" and "Section III: Seeds for planting" of the UK "Import requirements for plants, plant produce and products"). The sealed bags, after inspection and replacement of silica gel if required, were then stored in $4{ }^{\circ} \mathrm{C}$ in plastic boxes containing silica gel until flow cytometry analysis.

5. The seeds received from VIR, USDA and CIAT were germinated in a tropical greenhouse $\left(25^{\circ} \mathrm{C}\right)$, and leaf samples were collected from plants, and dried and preserved in the same way as those collected in the field in Colombia, and then used as standards for flow cytometry analysis. 


\subsection{Sample Preparation for Flow Cytometry}

Cell nuclei suspensions from dehydrated leaf tissues were prepared for flow cytometric analysis according to Doležel et al. [44] with minor modifications:

1. In total, $500 \mathrm{mg}$ of dried leaf of each accession were chopped with a sharp razor blade in a $55 \times 15 \mathrm{~mm}$ polystyrene Petri dish with ice cold $1 \mathrm{~mL}$ nucleus-isolation buffer. Much smaller amounts of leaf material $(100 \mathrm{mg})$ did not give suitable nuclear suspensions. We used double edge stainless razor blades, allocating one razor edge per one studied accession. For safe holding of the razor blade while chopping, a rubber grip was used.

2. Three different standard buffers were evaluated, as shown in Table 2. Buffers were supplemented with $15 \mathrm{mM} \beta$-mercaptoethanol (Calbiochem CAS 60-24-2) and 1\% PVP-40 (polyvinylpyrrolidone-40; Sigma PVP40) and the effect of these chemicals on reducing the negative effect of cytosolic and phenolic compounds was tested.

3. After finely chopping the material in the buffer, the nuclei suspension was passed through a $50 \mu \mathrm{m}$ mesh nylon filter (CellTrics, Sysmex 04-004-2327) into the $12 \times 75 \mathrm{~mm}$ round-bottom polystyrene flow cytometry tubes (Falcon ${ }^{\circledR} 352052$, with caps preventing cross-contamination), and placed on ice.

4. The nuclei suspension was then supplemented with propidium iodide (PI, Sigma P4170; $50 \mu \mathrm{g} \mathrm{mL}^{-1}$; solution in deionized water, passed through a $0.22 \mathrm{~mm}$ filter), and ribonuclease A (Sigma R6513; $50 \mu \mathrm{g} \mathrm{mL}^{-1}$ ) to prevent staining of double-stranded RNA, and mixed gently using vortex.

5. Samples were incubated for at least $10 \mathrm{~min}$ on ice in darkness, and then were analyzed in an Accuri C6 Flow Cytometer (Becton Dickinson), equipped with a $20 \mathrm{~mW}$ laser illumination operating at $488 \mathrm{~nm}$.

\subsection{Flow Cytometry Analysis}

In the first stage of the analysis, it was checked whether the dry and fresh samples gave the same results (fluorescence value of peak positions). The dry leaves were then used for the daily calibration of flow cytometer. For ploidy measurement, Panicum miliaceum Mil69 $(2 n=4 x=36)$ [45] was used as a primary external standard to recognize ploidy of some accessions of studied plants. Subsequent external standards were then included in the analyses, and their number of chromosomes was confirmed microscopically. We used the following protocol for the ploidy measurement:

1. Prior to measuring the ploidy of samples from a given species, the flow cytometer was calibrated using the specified external standard (Table 1). For calibration, we used VirtualGain tool. In the external standard plot, the Peak Definition Marker (see red line in Figure 2F) was manually moved to the center of the external standard peak, becoming the reference point. Samples to be measured were aligned to this position.

2. The histograms (FSC-A vs. SSC-A, FL1-A vs. FL2-A, FL3-A vs. FL2-A, and a univariate histogram of FL2-A) were acquired using the CFlow ${ }^{\circledR}$ Plus software set up according to Galbraith and Lambert [46]. Here, the following filter configurations were used: FL-1-a 530/14-nm bandpass filter; FL-2-a 585/20-nm bandpass filter; FL-3-a 670-nm longpass filter. The primary threshold was set to channel 10,000 on FSC-A to gate out debris and noise from nuclei suspension. The secondary threshold was set at 1000 for FL-2. Polygonal gating tool was used to draw a region on the FSC-A vs. SSC-A plot, and a line-shaped cluster of dots showing PI-stained nuclei in the biparametric dot plot of FL2-A vs. FL3-A. Based on this gating, G0/G1 and G2 peaks appeared in a univariate histogram of FL2-A.

3. The relative fluorescence values of the peak positions of PI-stained nuclei (FL) and the coefficient of variation (CV) of the G0/G1 peak to estimate nuclei integrity and variation in DNA staining were evaluated in each sample by manually placing regions of identification across the peak to export values.

4. Ploidy of studied plants was determined by comparing the fluorescence values of the peak positions of samples to that of external standards. 
Table 2. Nuclei isolation buffers and their compositions.

\begin{tabular}{|c|c|}
\hline Buffer & Composition \\
\hline Galbraith [47] & $45 \mathrm{mM} \mathrm{MgCl} 2,20 \mathrm{mM}$ MOPS, $30 \mathrm{mM}$ sodium citrate, $0.1 \%(v / v)$ Triton X-100 (pH 7) \\
\hline Otto $[48]$ & $\begin{array}{l}\text { Otto I: } 100 \mathrm{mM} \text { citric acid, } 0.5 \%(v / v) \text { Tween } 20\left(\mathrm{pH} \text { 2-3)Otto II: } 400 \mathrm{mM} \mathrm{Na}_{2} \mathrm{PO}_{4} \cdot 12 \mathrm{H}_{2} \mathrm{O}\right. \\
(\mathrm{pH} 8-9)\end{array}$ \\
\hline Modified Otto (this paper) & $\begin{array}{l}\text { Otto I: } 100 \mathrm{mM} \text { citric acid, } 0.5 \%(v / v) \text { Tween } 20 \text { (pH 2-3)Otto II: } 400 \mathrm{mM} \mathrm{Na}_{2} \mathrm{PO}_{4} \cdot 12 \mathrm{H}_{2} \mathrm{O}(\mathrm{pH} \\
\text { 8-9), } 15 \mathrm{mM} \beta \text {-mercaptoethanol, } 1 \% \text { PVP-40 }\end{array}$ \\
\hline Partec [49] & $100 \mathrm{mM}$ Tris, $2.5 \mathrm{mM} \mathrm{MgCl} 2 \cdot 6 \mathrm{H}_{2} \mathrm{O}, 85 \mathrm{mM} \mathrm{NaCl}, 0.1 \%(v / v)$ Triton X-100 $(\mathrm{pH} 7,0)$ \\
\hline Modified Partec (this paper) & $\begin{array}{c}100 \mathrm{mM} \text { Tris, } 2.5 \mathrm{mM} \mathrm{MgCl} 2 \cdot 6 \mathrm{H}_{2} \mathrm{O}, 85 \mathrm{mM} \mathrm{NaCl}, 0.1 \%(v / v) \text { Triton X-100 (pH 7.0), } 15 \mathrm{mM} \\
\beta \text {-mercaptoethanol, 1\% PVP-40 }\end{array}$ \\
\hline
\end{tabular}
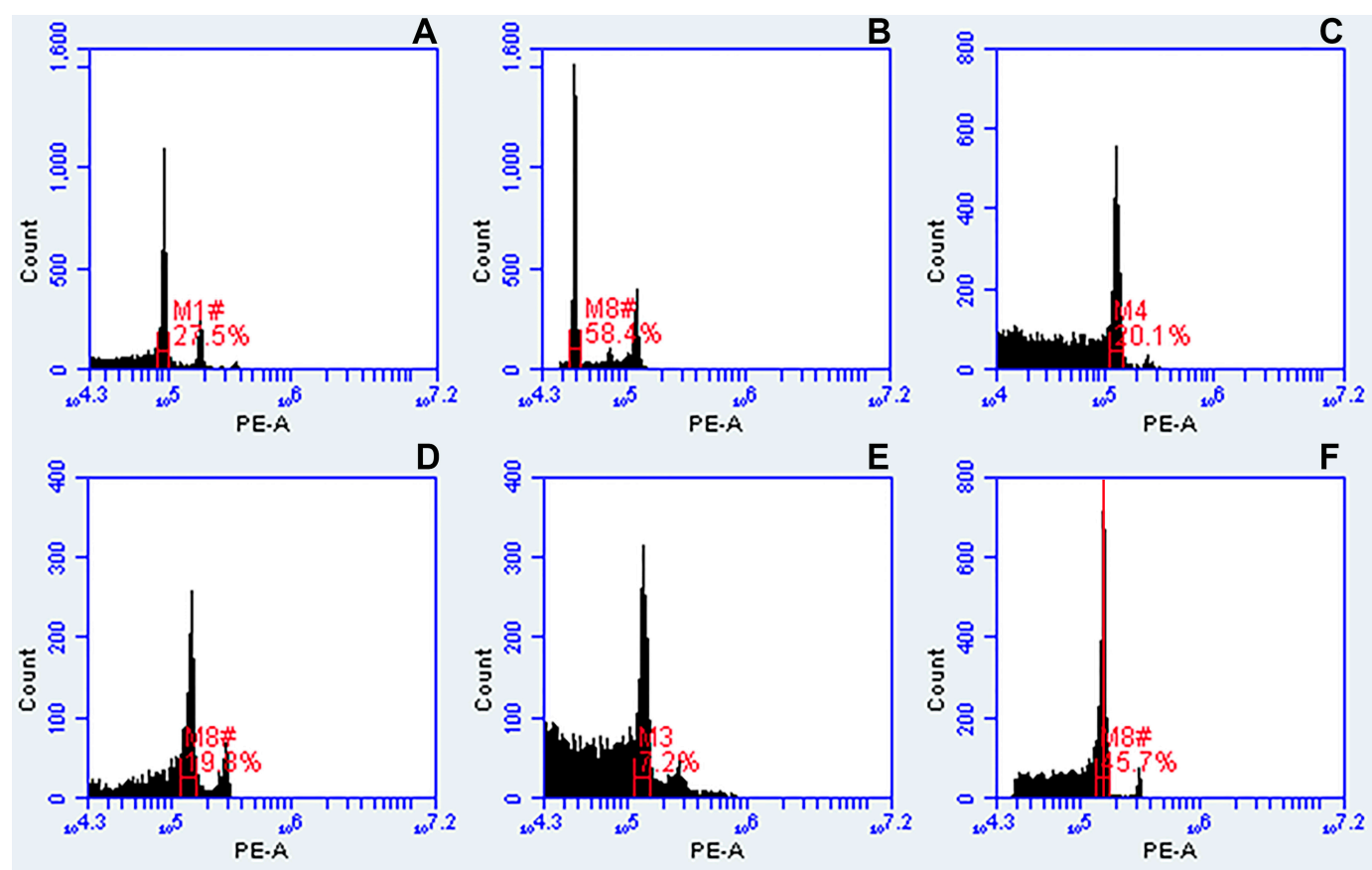

Figure 2. Optimization of flow cytometry assay for dried leaf samples. (A) Three gradually declined peaks of diploid $U$. decumbens CIAT 26185 indicating endoreduplication; (B) additional high peak in histogram of tetraploid U. maxima CIAT 16055, indicating contamination of leaf sample; (C) fresh and (D) dried leaf samples of Panicum miliaceum showing the same position of peaks in histograms, but slight differences in number of nuclei and CV of DNA peaks; (E) histogram of dried leaf sample of Panicum miliaceum with no gating tools applied; (F) histogram of dried leaf sample of Panicum miliaceum where gating tools were applied, giving sharp peaks and low background. Here, gain or peak height was adjusted using a software function (VirtualGain) and the center of the peak selected as reference point (red line; Peak Definition Marker). Regions of identification (red marks) were placed across the peaks to export fluorescence values representing peak positions and CVs (coefficient of variation of G0/G1 peaks).

\subsection{Microscopy and Validation of Chromosome Numbers}

For chromosome number calculation of external standards, we used a modified protocol of Schwarzacher and Heslop-Harrison [50]:

1. Urochloa seeds, like many other tropical grasses, did not germinate in Petri dishes. The seeds were germinated in a $25^{\circ} \mathrm{C}$ greenhouse, in $15 \times 15 \mathrm{~cm}$ plastic pots containing Levington $\mathrm{F} 2+\mathrm{S}$ soil.

2. Root tips were collected from plants cultivated in a greenhouse, treated with $\alpha$ bromonaphthalene (Sigma B73104) at room temperature for $2 \mathrm{~h}$, and $4{ }^{\circ} \mathrm{C}$ for $4 \mathrm{~h}$, and fixed in absolute ethyl alcohol:acetic acid solution, 3:1.

3. The root tips were washed in enzyme buffer ( $10 \mathrm{mM}$ citric acid/sodium citrate) for $15 \mathrm{~min}$, and then they underwent enzymatic maceration in $20 \mathrm{U} / \mathrm{mL}$ cellulase (Sigma 
C1184), $10 \mathrm{U} / \mathrm{mL}$ 'Onozuka' RS cellulase (RPI C32400) and $20 \mathrm{U} / \mathrm{mL}$ pectinase (Sigma P4716 from Aspergillus niger; solution in $40 \%$ glycerol) in $10 \mathrm{mM}$ enzyme buffer for 60 min at $37^{\circ} \mathrm{C}$.

4. Digested root tips were squashed in $60 \%$ acetic acid. Cover slips were removed after freezing with dry ice.

5. Air-dried slides were counterstained with DAPI (4',6-diamidino-2-phenylindole, Sigma D9542; $2 \mu \mathrm{g} \mathrm{mL}$ ) in antifade solution (Citifluor, Vectashield, Slowfade or any other commercial antifading reagents for fluorescence microscopy), which prevents the permanent loss of fluorescence due to prolonged exposure to high intensity light sources.

6. Slides were analyzed with an epifluorescence microscope with appropriate UV illumination, filters and camera (Nikon Eclipse 80i; DS-QiMc monochromatic camera, and NIS-Elements v.2.34 software, Nikon, Tokyo, Japan). The number of chromosomes was counted for approximately 50 metaphases derived from 5 plants of each accession used as potential external standard for flow cytometry.

\section{Results}

3.1. Optimization of Flow Cytometry Assay for Dried Leaves of Urochloa

\subsubsection{Flow Cytometry Troubleshooting}

Nuclei isolated from properly collected, dried and well-preserved leaf samples, as explained in materials and methods, gave histograms showing peaks from cells at different stages of the cell cycle: higher G0/G1 (2C) and lower G2 (4C) peaks. Sometimes more peaks were observed, like three gradually declined peaks in Figure 2A, indicating endoreduplication process. Use of older leaf collections gave DNA peaks having very high CVs (coefficient of variation of G0/G1 peaks), above $10 \%$, or additional peaks on the histogram (Figure 2B), and these samples were excluded from further analysis. Fresh and dried leaves gave very similar position of peaks, as shown in Figure 2C,D for comparison, however, sometimes the number of isolated nuclei from dried leaves was slightly smaller due to sample degradation. Several samples of one accession, where possible, were run as the position of the peak in the histogram may vary slightly between plants (Supplementary Data Table S1). In the example of Figure 2F, nuclei of interest were being selected (gated) in the FSC-A vs. SSC-A and FL2-A vs. FL3-A plots (as explained in materials and methods), resulting in sharper peaks of G0/G1 and G2 and lower background in univariate histogram of FL2-A, in comparison to Figure 2E where gating tools were not applied.

\subsubsection{Buffers}

Three different standard isolation buffers (Table 2) were tested to isolate nuclei from dehydrated Urochloa leaves. No peaks (Figure 3A) or very low peaks were obtained analyzing samples of nuclei isolated using Galbraith's buffer [47] which is optimized for fresh material. Small numbers of nuclei were isolated using Otto's buffer [48] giving histograms with increased level of background and high CVs (Figure 3B). Supplementation of Otto's buffer with $15 \mathrm{mM} \beta$-mercaptoethanol and 1\% PVP-40 only slightly increased the peak resolution (Figure $3 \mathrm{C}$ ). Well-defined histograms with acceptable $\mathrm{CV}$ values and reasonable number of nuclei (Figure 3D-F) were obtained using Partec buffer [49]. The sharpest peaks were yielded after supplementation of this buffer with $15 \mathrm{mM} \beta$-mercaptoethanol and $1 \%$ PVP-40 (Figure 3F). 

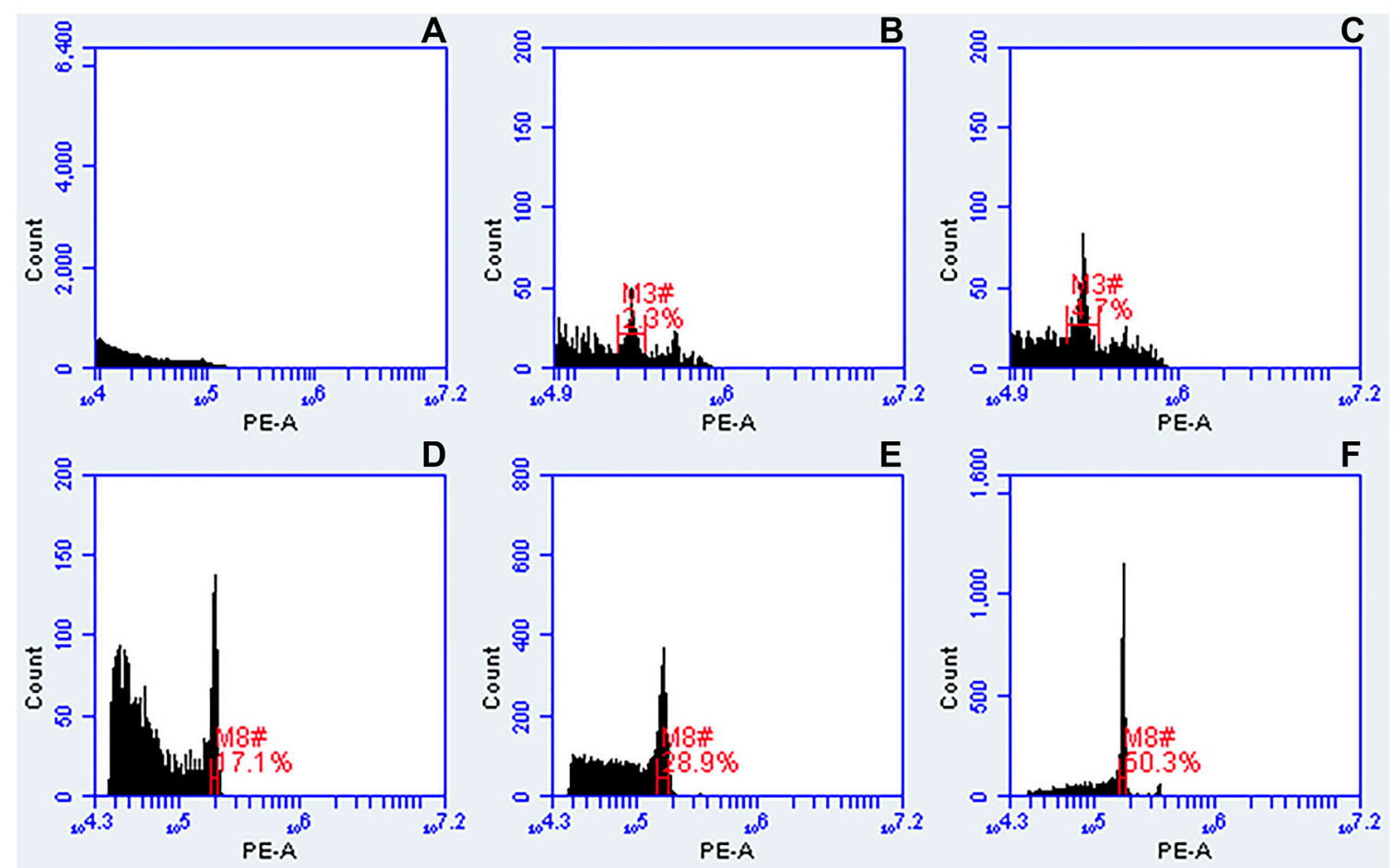

Figure 3. Comparison of three different standard buffers for nuclei isolation from dried leaves of tetraploid Urochloa accessions, and their effect on histogram quality. (A) Galbraith's buffer; (B) Otto's buffer; (C) Otto's buffer supplemented with $15 \mathrm{mM} \beta$-mercaptoethanol and 1\% PVP-40 (Modified Otto, see Table 2); (D) Partec buffer; (E) Partec buffer supplemented with $\beta$-mercaptoethanol; (F) Partec buffer supplemented with $15 \mathrm{mM} \beta$-mercaptoethanol and 1\% PVP-40 (Modified Partec, see Table 2). Regions of identification (red marks) were placed across the peaks to export fluorescence values representing peak positions and CVs.

\subsubsection{External Standards Used for Flow Cytometry Analysis}

The procedure of ploidy determination of Urochloa species using flow cytometry of dried leaf specimens was optimized by choosing appropriate buffer composition (Table 2, Figure 3), drying and preservation of plant samples (protocol in material and methods, Figure 2), chopping technique (Figure 2) and different external standards (Table 1). Panicum miliaceum Mil69 $(2 n=4 x=36)$ was used as a primary external standard to recognize accessions for which the level of ploidy was certain. Ten different accessions were selected as potential external standards. The ploidy of these plants was validated by preparing mitotic slides and counting chromosomes microscopically (Figure 4). The position of peaks of Urochloa humidicola CIAT 16867 in the histogram (Figure 4F) suggested that this accession was most likely to be heptaploid, but chromosome counting revealed it to be aneuploid with $2 n=8 x+2$ or $9 x-4=50$, thus, this accession was excluded from further analysis. The other nine accessions were then used as external standards, and their mean fluorescence values of the peak positions are given in Table 1. 

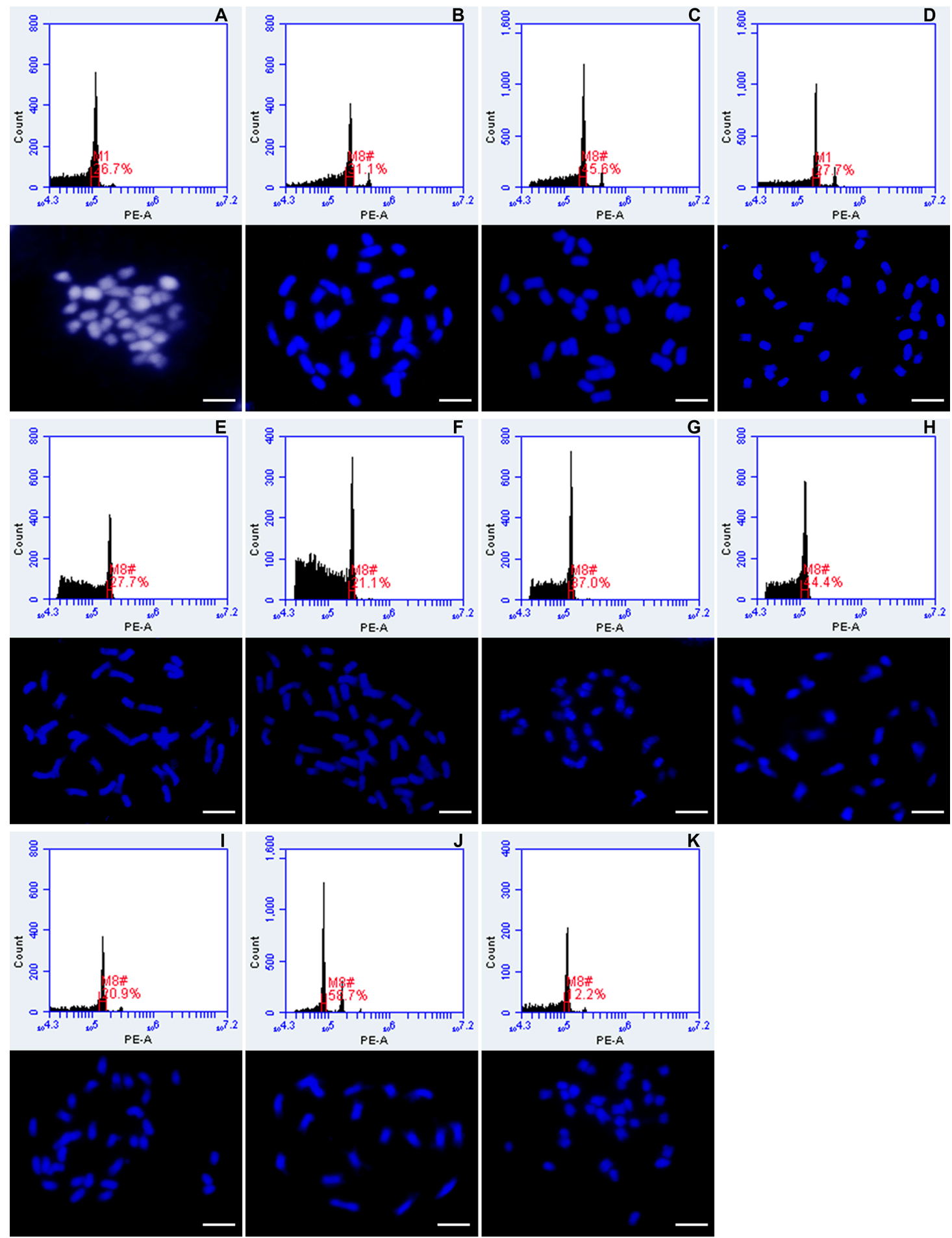

Figure 4. Histograms of relative fluorescence intensities showing ploidy levels and the corresponding chromosome numbers of different genotypes selected as potential external standards for flow cytometry analysis of Urochloa germplasm collection. (A) Panicum miliaceum Mil69 $(2 n=4 x=36)$; (B) Urochloa brizantha PI $292187(2 n=4 x=36)$; (C) Urochloa decumbens CIAT $664(2 n=4 x=36)$; (D) Urochloa decumbens CIAT $6370(2 n=4 x=36)$; (E) Urochloa humidicola CIAT $26151(2 n=6 x=36)$; (F) Urochloa humidicola CIAT $16867(2 n=8 x+2$ or $9 x-4=50)$, recognized as aneuploid and thus cannot be used as external standard; (G) Urochloa maxima CIAT $6171(2 n=4 x=32) ;(H)$ Urochloa maxima CIAT $16004(2 n=4 x=32)$; (I) Urochloa maxima PI 284156 ( $2 n=4 x=32)$; (J) Urochloa ruziziensis CIAT $6419(2 n=2 x=18)$; (K) Urochloa sp. PI $657653(2 n=4 x=32)$. Regions of identification seen in plots (red marks) were placed across the peaks to export fluorescence values representing peak positions and CVs. Scale bars $=5 \mu \mathrm{m}$. 


\subsection{Ploidy Measurement of Urochloa Species}

DNA content of 348 accessions of different Urochloa species were measured using flow cytometry of imported dried leaf materials using the optimized technique giving very sharp peaks. Fluorescence values of the peak positions and CVs were exported and are given in Supplementary Data Table S1 and summarized in Table 3. CV values were slightly increased comparing to the fresh leaf specimens of Panicum miliaceum (CV 2.5\%). Where possible, several leaf samples for one accession were measured enabling comparison of fluorescence values of the peak positions between different plants of the same accession. In general, these values did not differ significantly from plant to plant, proving the established method. The fluorescence values of the peak positions of samples were compared to that of the nine standards (Table 1), which allowed to establish that other species with a similar genome size and basic chromosome numbers can be used as external standards for ploidy measurements of our studied accessions. For each level of ploidy of the individual species, a range of fluorescence values of the peak positions were established (Table 3), and these ranges for the most numerous species are shown in Figure 5.

Table 3. Variation in fluorescence values of the peak positions between species, for the different ploidy levels determined.

\begin{tabular}{|c|c|c|c|c|c|c|c|}
\hline Species & Ploidy & $\begin{array}{l}\text { Number of } \\
\text { Studied } \\
\text { Accessions }\end{array}$ & $\begin{array}{c}\text { Number of } \\
\text { Studied Plants }\end{array}$ & $\begin{array}{l}\text { Range of } \\
\text { Fluorescence } \\
\text { Values of the } \\
\text { Peak Positions }\end{array}$ & $\begin{array}{l}\text { Mean } \\
\text { Fluorescence } \\
\text { Values of the } \\
\text { Peak Positions }\end{array}$ & CV (\%) Range & $\begin{array}{l}\text { CV (\%) } \\
\text { Average }\end{array}$ \\
\hline Urochloa arrecta & $2 n=4 x$ & 1 & 1 & 93 & 93 & 7.53 & 7.53 \\
\hline \multirow{4}{*}{ Urochloa brizantha } & $2 n=2 x$ & 6 & 9 & $82-110$ & 96 & $5.46-9.14$ & 7.32 \\
\hline & $2 n=4 x$ & 59 & 70 & $111-225$ & 172 & $2.9-9.89$ & 5.65 \\
\hline & $2 n=5 x$ & 25 & 37 & $215-291$ & 247 & $3.4-8.17$ & 5.34 \\
\hline & $2 n=6 x$ & 1 & 1 & 303 & 303 & 3.83 & 3.83 \\
\hline \multirow[t]{3}{*}{ Urochloa decumbens } & $2 n=2 x$ & 18 & 19 & $72-104$ & 87 & $2.68-6.87$ & 4.76 \\
\hline & $2 n=4 x$ & 25 & 28 & $152-211$ & 183 & $3.25-5.66$ & 4.52 \\
\hline & $2 n=6 x$ & 1 & 1 & 270 & 270 & 4.02 & 4.02 \\
\hline Urochloa dictyoneura & $2 n=7 x$ & 1 & 1 & 220 & 220 & 5.91 & 5.91 \\
\hline Urochloa dura & $2 n=5 x$ & 1 & 2 & $255-282$ & 268 & $4.82-5.18$ & 5 \\
\hline \multirow{4}{*}{ Urochloa humidicola } & $2 n=6 x$ & 16 & 21 & $108-205$ & 174 & $3.69-6.24$ & 4.65 \\
\hline & $2 n=7 x$ & 33 & 45 & $215-298$ & 259 & $2.84-6.4$ & 4.31 \\
\hline & $\begin{array}{c}2 n=8 x+2 \\
\text { or } 9 x-4\end{array}$ & 1 & 2 & $253-259$ & 256 & $3.04-3.49$ & 3.27 \\
\hline & $2 n=9 x$ & 3 & 4 & $320-338$ & 330 & $3.39-5.33$ & 4.7 \\
\hline \multirow[t]{2}{*}{ Urochloa jubata } & $2 n=2 x$ & 1 & 1 & 87 & 87 & 5.89 & 5.89 \\
\hline & $2 n=4 x$ & 1 & 1 & 123 & 123 & 4.73 & 4.73 \\
\hline \multirow[t]{2}{*}{ Urochloa maxima } & $2 n=2 x$ & 25 & 31 & $74-104$ & 94 & $4.81-9.23$ & 7.02 \\
\hline & $2 n=4 x$ & 99 & 102 & 104-190 & 128 & $3.73-8.81$ & 5.5 \\
\hline Urochloa nigropedata & $2 n=4 x$ & 1 & 2 & $142-146$ & 144 & $3.91-6.53$ & 5.22 \\
\hline Urochloa plantaginea & $2 n=2 x$ & 1 & 1 & 90 & 90 & 6.62 & 6.62 \\
\hline Urochloa platynota & $2 n=2 x$ & 1 & 1 & 98 & 98 & 5.96 & 5.96 \\
\hline $\begin{array}{l}\text { Urochloa ruziziensis } \\
\text { Urochloa ruziziensis } \times\end{array}$ & $2 n=2 x$ & 26 & 33 & 75-103 & 86 & $2.42-6.92$ & 4.32 \\
\hline $\begin{array}{l}\text { Urochloa decumbens } \times \\
\text { Urochloa brizantha }\end{array}$ & $2 n=4 x$ & 1 & 1 & 190 & 190 & 2.67 & 2.67 \\
\hline Urochloa sp. PI657653 & $2 n=4 x$ & 1 & 1 & 111 & 111 & 4.42 & 4.42 \\
\hline
\end{tabular}




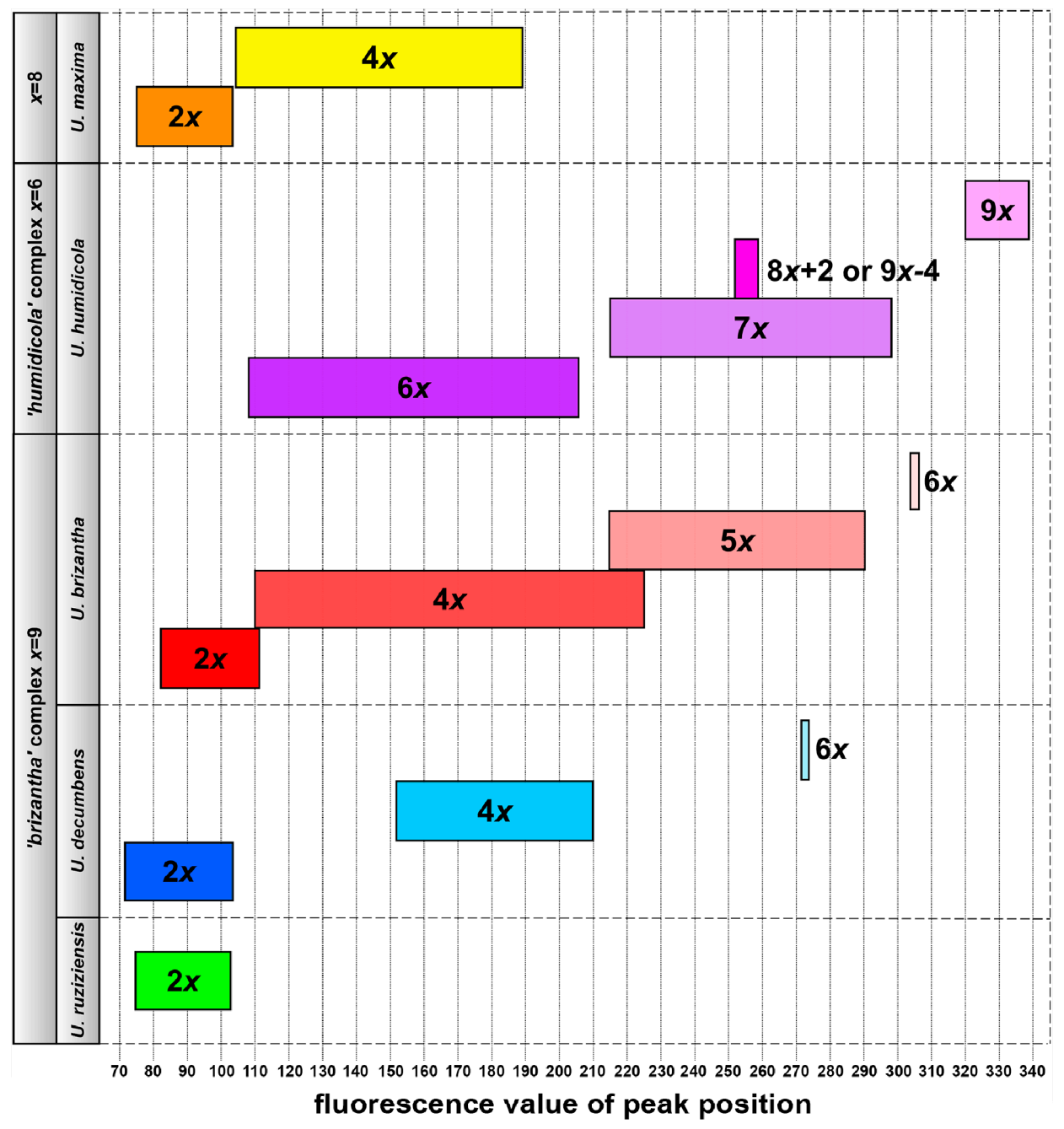

Figure 5. Ranges of fluorescence values of the peak positions for different ploidy levels of the most numerous species ('brizantha' agamic complex: U. ruziziensis, U. decumbens, U. brizantha; 'humidicola' agamic complex: U. humidicola; U. maxima) in CIAT germplasm collection.

\subsection{1. 'Brizantha' Agamic Complex}

Three species belonging to the 'brizantha' agamic complex, Urochloa ruziziensis, $U$. decumbens and $U$. brizantha, have a basic chromosome number $x=9$. All accessions of U. ruziziensis studied here were diploid (Supplementary Data Table S1), showing similar range of fluorescence values of the peak positions to that of diploid $U$. decumbens (see Table 3 and Figure 5). Within both species there are single samples showing higher fluorescence values of the peak positions than the others. U. decumbens accessions differ in their ploidy levels, showing diploids, tetraploids, and hexaploid (Supplementary Data Table S1), that can be clearly distinguishable using flow cytometry, because the ranges of fluorescence values of the peak positions for each ploidy level did not overlap. This result contrasts with $U$. brizantha, where the ranges the fluorescence values of the peak positions of diploids, tetraploids, pentaploids and hexaploids overlapped, meaning that ploidy levels of this species are not so obvious (see Figure 5). This is particularly evident when looking at the differences in fluorescence values between samples of the same accession (see Supplementary Data Table S1).

\subsection{2. 'Humidicola' Agamic Complex}

Two polyploid species with basic chromosome number $x=6$ were assigned to the 'humidicola' agamic complex: U. humidicola and U. dictyoneura. Three different ploidy 
levels were recognized in the U. humidicola: hexaploid, heptaploid, and nonaploid (Supplementary Data Table S1). U. dictyoneura accession used in our studies seemed to be heptaploid. In general, each ploidy level of $U$. humidicola has its own range of fluorescence values of the peak positions (Figure 5), however, due to confirmed aneuploidy within species (U. humidicola CIAT 16867 with $2 n=8 x+2$ or $9 x-4=50$ ), additional validation, e.g., counting chromosome numbers, would be needed.

\subsubsection{Urochloa Maxima}

Two ploidy levels were recognized in U. maxima. Some diploid and tetraploid accessions showed similar fluorescence values of the peak positions (Figure 5). Those samples that have extreme results and peaks well beyond those of the reference external standards should have their chromosomes counted.

\subsubsection{Related Species}

Several tropical grass species with potential for improvement and wider use as forages were studied here, including other cultivated and wild Urochloa species: U. arrecta, U. dura, $U$. jubata, $U$. nigropedata, $U$. plantaginea, and U. platynota. In our analysis, we also used one Urochloa accession not assigned to species (possible hybrid) and one synthetic multigeneration hybrid involving $U$. ruziziensis, $U$. decumbens and $U$. brizantha, both accessions having huge potential for sustainable grazing and pasture management. In all cases, our external standards were useful to establish ploidy levels of studied species.

\section{Discussion}

\subsection{Flow Cytometry as a Useful Tool for Measuring the Ploidy of Large Germplasm Pool}

Flow cytometry has become the standard technology for measuring the ploidy and genome sizes of plants [40], allowing the measurement of hundreds of samples, even genomically diverse species, in a relatively short time. In most cases, freshly collected, fieldor garden-grown leaf material is used, with a small number of accessions. We optimized the methods for sampling, drying, storage, transport and preservation of tropical forage grasses to use some time later with a robust flow cytometry protocol for measurement of ploidy. We show the utility in a relatively large and diverse germplasm collection (348 accessions) of the tropical forage grass genus Urochloa (previously placed in genus Brachiaria and some Eriochloa and Panicum) [51,52]. Our analysis proved that the requirement of fresh leaf material is not a crucial limitation for flow cytometry-based determination of ploidy, especially while screening a large germplasm pool $[36,43,53]$. The method allows wider field and geographical sampling of plants when fresh leaf tissues cannot be examined shortly after harvesting [54].

\subsection{Needs for Screening Urochloa Germplasm Collection}

Integration of ploidy levels and agronomic traits, especially those related to resistance and tolerance to pest and diseases, is important to define a breeding strategy to exploit germplasm with diverse ploidy levels $[5,55,56]$. Where collections have various ploidies, flow cytometry can help the verification of samples from field collections, where mislabeling, or spread of incorrect seed or plants in vegetative plots may lead to replacement of one accession with another over decades. Comparison of similar accessions numbers from Brazil and Colombia detects some such differences. Polyploidy promotes genome diversification and gives plasticity to species [57], thus it is pertinent to examine ploidy of as many accessions as possible in order to choose those suitable for crossbreeding. For research purposes, sampling and screening the large germplasm collections provides additional characters and helps to better estimate genome relationships between species within large plant complexes, such as Urochloa [1] and hence help reconstruct phylogenies, particularly those where reticulate evolution of polyploid taxa is found. Flow cytometry and the measurement of nuclear DNA contents has other applications not considered here, 
in particular for analysis of the cell cycle [58], and examining differentiation of cells through endopolyploidy [59].

\subsection{Choice of Flow Cytometry Approaches to Determine Ploidy from Dried Leaf Specimens}

We developed an optimized approach to determine ploidy of germplasm collection of the tropical forage grass genus Urochloa using dried leaf material. The analysis showed that our method enabled robust identification of ploidy levels from dehydrated specimens. The coefficient of variation of G0/G1 peaks (CV) of the samples studied here, was typically $<5 \%$, which is desirable, but analysis of much older leaves, e.g., herbarium specimens, can give broader peaks with a still usable CV between $5 \%$ and $10 \%$ [44].

The most suitable buffer for estimation of ploidy levels from both fresh and dried Urochloa leaves was Partec. Its components include Tris as buffer, $\mathrm{NaCl}(85 \mathrm{mM})$ to maintain nuclear integrity, $\beta$-mercaptoethanol as antioxidant, and PVP-40 (polyvinylpyrrolidone-40) to bind polyphenols and anthocyanins, scavenge other polar molecules and deactivate proteins from the plant cells; Triton X-100 as a detergent to aid buffer penetration. The Partec buffer was successfully used on plants rich in secondary metabolites, such as Lupinus, Brassica, Cocos, Matricaria or Cyclopia. In other species, however, this buffer did not produce peaks, and the high concentration of specific polyphenols in Aspalathus inhibited nuclei isolation [60], thus each group of plants requires several buffers to be tested to obtain very sharp peaks and reliable results.

In our ploidy analysis we used propidium iodide (PI) which is one of the most widely used fluorescence reagents in flow cytometry binding to DNA by intercalating between DNA bases and showing no AT or GC preference. Its fluorescence with green-light excitation is enhanced some 20-fold when bound to DNA compared to in solution. The emission maximum depends on the solvent, and in the aqueous solution used for nuclear isolation, the maximum is $636 \mathrm{~nm}$ (red) [61]. PI shows intermolecular proton transfer reaction in solvent; it interacts with SDS (sodium dodecyl sulphate), thus we avoided this widely used detergent and did not use it as a component of a nuclei isolation buffer for flow cytometry. Propidium iodide also binds to RNA, showing enhanced fluorescence (with a slightly different fluorescent color), so for nuclear staining, RNase needs to be added to the buffer. In practice, the concentration of PI and RNase in the buffer is important, and peaks broaden (higher CV) when they are too high or too low. In our analysis we used exactly the same concentration of PI and RNase, which allowed to obtain reliable results.

\subsection{Urochloa Germplasm Findings}

Here, we verified ploidy of 348 accessions of different Urochloa species, which represent a significant proportion of CIAT germplasm resources. However, determining the ploidy levels of grass group showing both apomictic and sexual mode of reproduction, like Urochloa, can become a challenge and requires the use of appropriate standards of known ploidy and number of chromosomes [62]. For Urochloa grass complex, different internal standards were needed due to the different genome sizes within and between agamic complexes and species, and different basic chromosome numbers (Supplementary Data Table S1). The average DNA content and genome sizes given as Cx values have been published already for Urochloa species [27,63]. Most diploid accessions of $U$. brizantha studied here are apomict [9], showing larger fluorescence values of the peak positions than sexual diploid accessions of $U$. decumbens and $U$. ruziziensis, proving that the genome size depends on the mode of reproduction [63], which is an additional challenge for screening diverse germplasm collections. While in diploid and polyploid accessions of $U$. decumbens a small shift in peak position on histogram usually does not compromise reliability of ploidy estimates, attention should be paid to the analysis of $U$. brizantha showing odd ploidy levels, because relative differences in fluorescence values of the peak positions between neighboring cytotypes $(2 x, 4 x, 5 x, 6 x)$ is decreased; such a phenomenon is also observed in species with ploidy levels greater than 6x [44]. A more precise examination of 
U. humidicola is also required due to confirmed aneuploidy [28,29], odd ploidy levels [34], and unrecognized diploid ancestors [64].

\section{Conclusions}

Urochloa tropical forage grasses have a great potential for sustainable agriculture and intensive grazing management of cover crops. Some of them are included in the current breeding programs at CIAT and EMBRAPA, now mainly focused on crossing tetraploids within 'brizantha' and 'humidicola' agamic complexes and Urochloa maxima [65], but other species studied here can also be included and used as fodder plants. This tropical forage grass group is genomically complex [9], having species recognized as being very variable in number of chromosomes, and ploidy levels which is the result of apomictic reproduction, and reflecting the genetic diversity present in a given population [66]. The ploidy levels of some Urochloa accessions have been previously measured [25,65,67-69], but some data vary between papers and reports [9]: thus, values may require checking for a particular accession name.

Supplementary Materials: The following are available online at https:/ /www.mdpi.com/article/10 .3390/genes12070957/s1, Supplementary Data Table S1. List of accessions used in the study, their fluorescence values of the peak positions, and coefficient of variations (CVs) of the G0/G1 peaks.

Author Contributions: Conceptualization, P.T., T.K.P. and P.H.-H.; Data curation, P.T., T.K.P. and L.M.H.; Formal analysis, P.T.; Funding acquisition, R.A.C.M., J.J.d.V. and P.H.-H.; Investigation, P.T.; Methodology, P.T., T.K.P. and V.C.; Project administration, P.H.-H.; Supervision, P.H.-H.; Validation, P.T.; Visualization, P.T.; Writing—original draft, P.T.; Writing—review \& editing, P.T., T.K.P., L.M.H., R.A.C.M., V.C., J.J.d.V., T.S. and P.H.-H. All authors have read and agreed to the published version of the manuscript.

Funding: This work was supported under the RCUK-CIAT Newton-Caldas Initiative "Exploiting biodiversity in Brachiaria and Panicum tropical forage grasses using genetics to improve livelihoods and sustainability", with funding from UK's Official Development Assistance Newton Fund awarded by UK Biotechnology and Biological Sciences Research Council (BB/R022828/1). P.T. has received further support from the European Union's Horizon 2020 research and innovation programme under the Marie Sklodowska-Curie grant agreements No 844564 and No 101006417. Open access charge was financially supported by the Leicester Research Archive, University of Leicester.

Institutional Review Board Statement: Not applicable.

Informed Consent Statement: Not applicable.

Data Availability Statement: Not applicable.

Acknowledgments: We would like to thank Jennifer Hincks from The Centre for Core Biotechnology Services, Flow Cytometry Facility at University of Leicester, for assistance with developing our flow cytometry protocol.

Conflicts of Interest: The authors declare no conflict of interest.

\section{References}

1. González, A.T.; Morton, C. Molecular and morphological phylogenetic analysis of Brachiaria and Urochloa (Poaceae). Mol. Phylogenetics Evol. 2005, 37, 36-44. [CrossRef]

2. Renvoize, S.A.; Clayton, W.D.; Kabuye, C.H.S. Morphology, taxonomy, and natural distribution of Brachiaria (Trin.) Griseb. In Brachiaria: Biology, Agronomy, and Improvement; Miles, J.W., Maass, B.L., do Valle, C.B., Kumble, V., Eds.; Centro Internacional de Agricultura Tropical (CIAT): Rome, Italy, 1996; pp. 1-15.

3. Keller-Grein, G.; Maass, B.L.; Hanson, J. Natural variation in Brachiaria and existing germplasm collections. In Brachiaria: Biology, Agronomy, and Improvement; Miles, J.W., Maass, B.L., do Valle, C.B., Kumble, V., Eds.; Centro Internacional de Agricultura Tropical (CIAT): Rome, Italy, 1996; pp. 16-39.

4. Capstaff, N.M.; Miller, A.J. Improving the yield and nutritional quality of forage crops. Front. Plant Sci. 2018, 9, 535. [CrossRef] [PubMed]

5. $\quad$ Barrios, S.C.; Valle, C.B.D.; Alves, G.F.; Simeão, R.M.; Jank, L. Reciprocal recurrent selection in the breeding of Brachiaria decumbens. Trop. Grasslands-Forrajes Trop. 2013, 1, 52. [CrossRef] 
6. Hanley, S.J.; Pellny, T.K.; de Vega, J.J.; Castiblanco, V.; Arango, J.; Eastmond, P.J.; Heslop-Harrison, J.S.; Mitchell, R.A.C. Allele mining in diverse accessions of Urochloa and Megathyrsus spp. tropical grasses to improve forage quality and reduce environmental impact. bioRxiv Prepr. 2020. [CrossRef]

7. Baptistella, J.L.C.; De Andrade, S.A.L.; Favarin, J.L.; Mazzafera, P. Urochloa in tropical agroecosystems. Front. Sustain. Food Syst. 2020, 4, 119. [CrossRef]

8. Ochatt, S.J. Flow cytometry in plant breeding. Cytom. Part A 2008, 73, 581-598. [CrossRef]

9. Tomaszewska, P.; Vorontsova, M.S.; Renvoize, S.A.; Ficinski, S.Z.; Tohme, J.; Schwarzacher, T.; Castiblanco, V.; de Vega, J.J.; Mitchell, R.A.C.; Heslop-Harrison, J.S. Complex polyploid and hybrid species in an apomictic and sexual tropical forage grass group: Genomic composition and evolution in Urochloa (Brachiaria) species. bioRxiv Prepr. 2021. [CrossRef]

10. Heslop-Harrison, J.S.; Schwarzacher, T. Flow cytometry and chromosome sorting. In Plant Chromosomes: Laboratory Methods; Fukui, K., Nakayama, S., Eds.; CRC: Boca Raton, FL, USA, 1996; pp. 85-108.

11. Doležel, J.; Lysák, M.A.; van Den Houwe, I.; Dolezelová, M.; Roux, N. Use of flow cytometry for rapid ploidy determination in Musa species. Infomusa 1997, 6, 6-9.

12. Schwarzacher, T.; Wang, M.L.; Leitch, A.R.; Moore, G.; Heslop-Harrison, J.; Miller, N. Flow cytometric analysis of the chromosomes and stability of a wheat cell-culture line. Theor. Appl. Genet. 1997, 94, 91-97. [CrossRef]

13. Bennett, M.D.; Bhandol, P.; Leitch, I.J. Nuclear DNA amounts in Angiosperms and their modern uses—807 new estimates. Ann. Bot. 2000, 86, 859-909. [CrossRef]

14. Śliwińska, E. Flow cytometry-A modern method for exploring genome size and nuclear DNA synthesis in horticultural and medicinal plant species. Folia Hortic. 2018, 30, 103-128. [CrossRef]

15. Loureiro, J.; Rodriguez, E.; Doležel, J.; Santos, C. Flow cytometric and microscopic analysis of the effect of tannic acid on plant nuclei and estimation of DNA content. Ann. Bot. 2006, 98, 515-527. [CrossRef] [PubMed]

16. Bennett, M.D.; Price, H.J.; Johnston, J.S. Anthocyanin inhibits propidium iodide DNA fluorescence in Euphorbia pulcherrima: Implications for genome size variation and flow cytometry. Ann. Bot. 2007, 101, 777-790. [CrossRef] [PubMed]

17. Greilhuber, J. Cytochemistry and C-values: The less-well-known world of nuclear DNA amounts. Ann. Bot. 2007, 101, 791-804. [CrossRef] [PubMed]

18. Price, H.J.; Hodnett, G.; Johnston, J.S. Sunflower (Helianthus annuus) leaves contain compounds that reduce nuclear propidium iodide fluorescence. Ann. Bot. 2000, 86, 929-934. [CrossRef]

19. Jędrzejczyk, I.; Śliwińska, E. Leaves and seeds as materials for flow cytometric estimation of the genome size of 11 Rosaceae woody species containing DNA-staining inhibitors. J. Bot. 2010, 2010, 1-9. [CrossRef]

20. Ooka, J.K.; Owens, D.K. Allelopathy in tropical and subtropical species. Phytochem. Rev. 2018, 17, 1225-1237. [CrossRef]

21. Ribeiro, R.C.; de Carvalho, M.G.; Lopes, H.M.; Rossiello, R.O.P.; Junior, É.B. Allelopathic activity of the hydrolate and water decoction of Brachiaria humidicola (Rendle) plant parts on the germination of four tropical leguminous species. ISRN Agron. 2012, 2012, 1-6. [CrossRef]

22. Ribeiro, R.C.; de Carvalho, M.G.; Moraes, M.D.L.; Rossiello, R.O.P.; de Oliveira, D.R.; de Amorim, R.M.Q.; Junior, E.B. Chemical screening of Urochloa humidicola: Methods for characterizing secondary metabolites and allelopathic activity on forage legumes. Am. J. Plant Sci. 2018, 09, 1260-1278. [CrossRef]

23. De Oliveira, D.R.; Nepomuceno, D.D.; Castro, R.N.; Filho, R.B.; De Carvalho, M.G. Special metabolites isolated from Urochloa humidicola (Poaceae). An. Acad. Bras. Ciências 2017, 89, 789-797. [CrossRef]

24. Feitoza, R.B.B.; Varela, R.M.; Torres, A.; Molinillo, J.M.G.; Lima, H.R.P.; Moraes, L.F.D.; Da Cunha, M.; Macías, F.A. Evaluation of the phytotoxicity of Urochloa humidicola roots by bioassays and microscopic analysis. Characterization of new compounds. J. Agric. Food Chem. 2020, 68, 4851-4864. [CrossRef] [PubMed]

25. Penteado, M.I.O.; Santos, A.C.M.; Rodrigues, I.F.; do Valle, C.B.; Seixas, M.A.C.; Esteves, A. Determinação de Ploidia e Avaliação da Quantidade de DNA Total Emdiferentesespécies do Gênero Brachiaria; Embrapa Gado de Corte: Campo Grande, Brasil, 2000.

26. Roche, D.; Hanna, W.W.; Ozias-Akins, P. Is supernumerary chromatin involved in gametophytic apomixis of polyploid plants? Sex. Plant Reprod. 2001, 13, 343-349. [CrossRef]

27. Timbó, A.L.D.O.; Pereira, R.C.; Sobrinho, F.S.; Davide, L.C. Nuclear DNA content and chromosome number in Brachiaria spp. genotypes. Rev. Ciência Agronômica 2014, 45, 62-67. [CrossRef]

28. Moraes, I.D.C.; Rume, G.D.C.; Sobrinho, F.S.; Techio, V.H. Characterization of aneuploidy in interspecific hybrid between Urochloa ruziziensis (R. Germ. \& Evrard) Crins and Urochloa decumbens (Stapf) R. D. Webster. Mol. Biol. Rep. 2019, 46, 1931-1940. [CrossRef]

29. Da Rocha, M.J.; Chiavegatto, R.B.; Damasceno, A.G.; Rocha, L.C.; Sobrinho, F.S.; Techio, V.H. Comparative meiosis and cytogenomic analysis in euploid and aneuploid hybrids of Urochloa P. Beauv. Chromosome Res. 2019, 27, 333-344. [CrossRef]

30. de Wet, J.M.J. Hybridization and polyploidy in the Poaceae. In Grass Systematics and Evolution; Soderstrom, T.R., Hilu, W.H., Campbell, W., Barkworth, M.E., Eds.; Smithsonian Institution Press: Washington, DC, USA, 1986; pp. $179-187$.

31. Basappa, G.P.; Muniyamma, M.; Chinnappa, C.C. An investigation of chromosome numbers in the genus Brachiaria (Poaceae: Paniceae) in relation to morphology and taxonomy. Can. J. Bot. 1987, 65, 2297-2309. [CrossRef]

32. Bernini, C.; Marin-Morales, M. Karyotype analysis in Brachiaria (Poaceae) species. Cytobios 2001, 104, 157-171.

33. Risso-Pascotto, C.; Pagliarini, M.S.; Valle, C.B.D. A new basic chromosome number for the genus Brachiaria (Trin.) Griseb. (Poaceae: Panicoideae: Paniceae). Genet. Resour. Crop. Evol. 2006, 53, 7-10. [CrossRef] 
34. Boldrini, K.; Pagliarini, M.; Valle, C. Meiotic behavior of a nonaploid accession endorses $\mathrm{x}=6$ for Brachiaria humidicola (Poaceae). Genet. Mol. Res. 2009, 8, 1444-1450. [CrossRef]

35. Worthington, M.; Ebina, M.; Yamanaka, N.; Heffelfinger, C.; Quintero, C.; Zapata, Y.P.; Perez, J.G.; Selvaraj, M.; Ishitani, M.; Duitama, J.; et al. Translocation of a parthenogenesis gene candidate to an alternate carrier chromosome in apomictic Brachiaria humidicola. BMC Genom. 2019, 20, 41. [CrossRef]

36. Suda, J.; Trávníček, P. Reliable DNA ploidy determination in dehydrated tissues of vascular plants by DAPI flow cytometry-New prospects for plant research. Cytom. Part A 2006, 69, 273-280. [CrossRef]

37. Bennett, M.D.; Smith, J.B. Nuclear DNA amounts in angiosperms. Philos. Trans. R. Soc. B Biol. Sci. 1976, 274, 227-274. [CrossRef]

38. Bennett, M.D.; Smith, J.B.; Heslop-Harrison, J.S. Nuclear DNA amounts in angiosperms. Proc. R. Soc. Lond. Ser. B Boil. Sci. 1982, 216, 179-199. [CrossRef]

39. Arumuganathan, K.; Earle, E.D. Estimation of nuclear DNA content of plants by flow cytometry. Plant Mol. Biol. Rep. 1991, 9 , 229-241. [CrossRef]

40. Doležel, J.; Bartoš, J. Plant DNA flow cytometry and estimation of nuclear genome size. Ann. Bot. 2005, 95, 99-110. [CrossRef] [PubMed]

41. Bennett, M.D.; Leitch, I.J. Nuclear DNA amounts in angiosperms: Targets, trends and tomorrow. Ann. Bot. 2011, 107, 467-590. [CrossRef] [PubMed]

42. Loureiro, J.; Rodriguez, E.; Dolezel, J.; Santos, C. Comparison of four nuclear isolation buffers for plant DNA flow cytometry. Ann. Bot. 2006, 98, 679-689. [CrossRef] [PubMed]

43. Roberts, A.V. The use of bead beating to prepare suspensions of nuclei for flow cytometry from fresh leaves, herbarium leaves, petals and pollen. Cytom. Part A 2007, 71, 1039-1044. [CrossRef]

44. Doležel, J.; Greilhuber, J.; Suda, J. Estimation of nuclear DNA content in plants using flow cytometry. Nat. Protoc. 2007, 2, 2233-2244. [CrossRef]

45. Hunt, H.V.; Badakshi, F.; Romanova, O.; Howe, C.J.; Jones, M.K.; Heslop-Harrison, J. (Pat) Reticulate evolution in Panicum (Poaceae): The origin of tetraploid broomcorn millet, P. miliaceum. J. Exp. Bot. 2014, 65, 3165-3175. [CrossRef]

46. Galbraith, D.W.; Lambert, G.M. Using the BD AccuriTM C6 cytometer for rapid and accurate analysis of the nuclear DNA contents of flowering plants. BD Bioscience 2021, 1, 1-10.

47. Galbraith, D.W.; Harkins, K.R.; Maddox, J.R.; Ayres, N.M.; Sharma, D.P.; Firoozabady, E. Rapid flow cytometric analysis of the cell cycle in intact plant tissues. Science 1983, 220, 1049-1051. [CrossRef] [PubMed]

48. Otto, F. Preparation and staining of cells for high-resolution DNA analysis. In Flow Cytometry and Cell Sorting; Radbruch, A., Ed.; Springer: Berlin/Heidelberg, Germany, 1992; pp. 101-104.

49. de Laat, A.M.M.; Göhde, W.; Vogelzang, J.D.C. Determination of ploidy of single plants and plant populations by flow cytometry. Plant Breed. 1987, 99, 303-307. [CrossRef]

50. Schwarzacher, T.; Heslop-Harrison, J.S. Practical In Situ Hybridization; Bios: Oxford, UK, 2000.

51. Salariato, D.L.; Zuloaga, F.O.; Giussani, L.M.; Morrone, O. Molecular phylogeny of the subtribe Melinidinae (Poaceae: Panicoideae: Paniceae) and evolutionary trends in the homogenization of inflorescences. Mol. Phylogenetics Evol. 2010, 56, 355-369. [CrossRef]

52. Salariato, D.L.; Morrone, O.; Zuloaga, F.O. Mayariochloa, a new monotypic genus segregated from Scutachne (Poaceae, Panicoideae, Paniceae). Syst. Bot. 2012, 37, 105-116. [CrossRef]

53. Šmarda, P.; Stančík, D. Ploidy level variability in South American Fescues (Festuca L., Poaceae): Use of flow cytometry in up to 5 $\frac{1}{2}$-year-old caryopses and herbarium specimens. Plant Biol. 2008, 8, 73-80. [CrossRef] [PubMed]

54. Wang, G.; Yang, Y. The effects of fresh and rapid desiccated tissue on estimates o Ophiopogoneae genome size. Plant Divers. 2016, 38, 190-193. [CrossRef] [PubMed]

55. Alves, G.F.; De Figueiredo, U.J.; Filho, A.D.P.; Barrios, S.C.; Valle, C.B.D. Breeding strategies for Brachiaria spp. to improve productivity-An ongoing project. Trop. Grasslands-Forrajes Trop. 2014, 2, 1. [CrossRef]

56. Matias, F.I.; Barrios, S.C.L.; Valle, C.B.D.; Mateus, R.G.; Martins, L.B.; Moro, G.V. Estimate of genetic parameters in Brachiaria decumbens hybrids. Crop. Breed. Appl. Biotechnol. 2016, 16, 115-122. [CrossRef]

57. Soltis, D.E.; Soltis, P.S. The dynamic nature of polyploid genomes. Proc. Natl. Acad. Sci. USA 1995, 92, 8089-8091. [CrossRef]

58. Francis, D.; Davies, M.S.; Barlow, P.W. A strong nucleotypic effect on the cell cycle regardless of ploidy level. Ann. Bot. 2008, 101, 747-757. [CrossRef] [PubMed]

59. Bhosale, R.; Boudolf, V.; Cuevas, F.; Lu, R.; Eekhout, T.; Hu, Z.; Van Isterdael, G.; Lambert, G.M.; Xu, F.; Nowack, M.K.; et al. A spatiotemporal DNA endoploidy map of the Arabidopsis root reveals roles for the endocycle in root development and stress adaptation. Plant Cell 2018, 30, 2330-2351. [CrossRef] [PubMed]

60. Mgwatyu, Y.; Stander, A.A.; Ferreira, S.; Williams, W.; Hesse, U. Rooibos (Aspalathus linearis) genome size estimation using flow cytometry and k-mer analyses. Plants 2020, 9, 270. [CrossRef] [PubMed]

61. Samanta, A.; Paul, B.K.; Guchhait, N. Photophysics of DNA staining dye propidium iodide encapsulated in bio-mimetic micelle and genomic fish sperm DNA. J. Photochem. Photobiol. B Biol. 2012, 109, 58-67. [CrossRef]

62. Krahulcová, A.; Rotreklová, O. Use of flow cytometry in research on apomictic plants. Preslia 2010, 82, 23-39.

63. Ishigaki, G.; Gondo, T.; Ebina, M.; Suenaga, K.; Akashi, R. Estimation of genome size in Brachiaria species. Grassl. Sci. 2010, 56, 240-242. [CrossRef] 
64. Boldrini, K.; Micheletti, P.; Gallo, P.; Mendes-Bonato, A.; Pagliarini, M.; Valle, C. Origin of a polyploid accession of Brachiaria humidicola (Poaceae: Panicoideae: Paniceae). Genet. Mol. Res. 2009, 8, 888-895. [CrossRef]

65. Triviño, N.J.; Perez, J.G.; Recio, M.E.; Ebina, M.; Yamanaka, N.; Tsuruta, S.-I.; Ishitani, M.; Worthington, M. Genetic diversity and population structure of Brachiaria species and breeding populations. Crop. Sci. 2017, 57, 2633-2644. [CrossRef]

66. Jank, L.; Valle, C.B.; Resende, R. Breeding tropical forages. Crop. Breed. Appl. Biotechnol. 2011, 11, 27-34. [CrossRef]

67. Jungmann, L. Caracterização da Diversidadegenética Molecular Emgermoplasma de Brachiaria spp. Ph.D. Thesis, Universidade Estadual de Campinas, São Paulo, Brasil, 2009.

68. Jungmann, L.; Vigna, B.B.; Boldrini, K.R.; Sousa, A.C.; Valle, C.B.D.; Resende, R.M.; Pagliarini, M.S.; Zucchi, M.I.; De Souza, A.P. Genetic diversity and population structure analysis of the tropical pasture grass Brachiaria humidicola based on microsatellites, cytogenetics, morphological traits, and geographical origin. Genome 2010, 53, 698-709. [CrossRef]

69. Nitthaisong, P.; Ishigaki, G.; Tanaka, H.; Akashi, R. Chromosome number, genomic variation, and molecular markers to assess genetic diversity of Brachiaria species. Crop. Sci. 2016, 56, 312-321. [CrossRef] 